\title{
Joyful Learning Berbasis Picture Cards Meningkatkan Minat Belajar Siswa pada Pembelajaran IPS di Era New Normal
}

\section{Siti Arafat ${ }^{*}$, Agustina Pali²}

1,2 Program Studi Pendidikan Guru Sekolah Dasar, Universitas Flores, Ende, Indonesia

\begin{tabular}{l} 
A R T I C L E I N F O \\
\hline Article history: \\
Received 1 Januari 2021 \\
Received in revised form \\
30 Januari 2021 \\
Accepted 1 Maret 2021 \\
Available online 8 April \\
2021 \\
\hline Kata Kunci: \\
Joyful Learning, Minat \\
Belajar \\
Keywords: \\
Joyful Learning, Learning \\
Interesting
\end{tabular}
dapat disimpulkan bahwa pendekatan Joyful Learning berbasis Picture Cards dapat dijadikan metode alternatif dalam pembelajaran karena dapat meningkatkan minat belajar siswa.

\section{A B S T R A C T}

The teacher-centered learning paradigm has an impact on the low interest of students in learning participation. One solution that can be applied is by implementing an innovative learning model that stimulates student interest in learning. This study aims to analyze the significance of the increase in student interest in social studies learning through the Picture Cards-based Joyful Learning model in online learning. This research is a classroom action research with 21 research subjects. Data were collected through interviews, observations, tests, documentation, and questionnaires. Data were analyzed using quantitative descriptive analysis techniques. The results showed that there was an increase in student interest in learning in the first cycle of $52.63 \%$ and $68.42 \%$ in the second cycle. The average value of an increase in student interest in learning in cycle I was 84, 21 and the average value of an increase in student interest in learning in cycle II was 91 . The significance of an increase in student interest in learning from cycle I to cycle II was 6.79 and can be classified as very good category. Thus it can be concluded that the Picture Cards-based Joyful Learning approach can be used as an alternative method of learning because it can increase student interest in learning.

\section{Pendahuluan}

Pandemi Covid-19 berdampak pada berbagai sektor kehidupan manusia di dunia (Basilaia \& Kvavadze, 2020; Gamage et al., 2020). Hal ini berimplikasi pada menurunnya produktivitas berbagai sektor yang mempengaruhi kehidupan manusia, salah satunya adalah sektor pendidikan pendidikan. Meskipun demikian, pendidikan harus tetap menunjukan eksistensinya karena pendidikan berperan penting dalam membentuk dan mengembangkan kualitas peradaban manusia (Xin et al., 2020). Eksistensi pendidikan pada saat ini dapat ditunjukan secara nyata melalui interaksi dalam pembelajaran yang pada saat ini dikenal dengan pembelajaran di era new normal (Wargadinata et al., 
2020; Xue et al., 2021). Pembelajaran di new normal era memiliki tantangan yang jauh berbeda bagi segenap komunitas pendidikan jika dibandingkan dengan masa-masa sebelumnya (Karalis, 2020; Tria, 2020). Setiap subjek dalam komunitas ini dituntut untuk meningkatkan kreatifitas dalam pembelajaran dan melakukan aktivitas-aktivitas pembelajaran yang seyogyanya dapat membantu siswa agar dapat beradaptasi dalam era kenormalan baru ini (Cahapay, 2020; Crawford et al., 2020).

Pembelajaran dalam situasi pandemi Covid-19 hendaknya dirancang dengan membangkitkan minat belajar siswa (Firman \& Rahman, 2020; Wijayanengtias \& Claretta, 2020). Berdasarkan hasil wawancara yang dilakukan kepada siswa dan penyebaran angket minat belajar siswa, ditemukan fakta yang menunjukan rendahnya minat belajar siswa secara khusus pada pembelajaran IPS karena intensitas kegiatan belajar di sekolah telah dikurangi, metode mengajar guru yang kurang variatif, minimnya penggunaan media pembelajaran di sekolah dan penumpukan tugas yang diberikan oleh guru mata pelajaran. Fenomena ini menjadi permasalahan yang harus segera diatasi karena dapat mempengaruhi kualitas output pembelajaran. Untuk itu rancangan pembelajaran pun harus menyenangkan, tanpa tekanan apalagi siksaan psikis (Pali \& Ota, 2020; Wijoyo \& Indrawan, 2020). Salah satu solusi yang dapat diterapkan untuk mengatasi masalah tersebut adalah dengan menerapkan model pembelajaran inovatif (Aqib \& Murtadlo, 2016; Shoimin, 2014).

Model pembelajaran inovatif merupakan model yang dapat memberikan kesempatan kepada peserta didik untuk membangun pengetahuan sendiri atau secara mandiri. Model pembelajaran inovatif lebih menekankan pembelajaran sebagai sesuatu yang menyenangkan dan membuat siswa berminat untuk mengikuti pembelajaran. Salah satu model pembelajaran yang mewakili ciri-ciri tersebut di atas adalah Joyful Learning. Model Joyful Learning adalah model pembelajaran yang menekankan pada pembelajaran aktif dan mengkolaborasikan konsep dan praktik sehingga menghasilkan pembelajaran yang bermakna (Anggoro et al., 2017; Fisher et al., 2015; Proity, 2015). Joyful learning memiliki unsur inner motivation yang dapat memicu dan mendorong siswa untuk memiliki daya juang dalam mencari tahu sesuatu (ilmu) yang baru (Huro et al., 2015; Juliati \& Rafiqah, 2017; Mubhirah et al., 2018).

Selain dengan menerapkan model pembelajaran yang inovatif, upaya peningkatan minat belajar siswa dapat dilakukan dengan menggunakan media pembelajaran yang menarik dalam proses pembelajaran (Asyhar, 2012; Ulfah \& Soenarto, 2017). Media pembelajaran yang menarik dapat meningkatkan ketertarikan siswa dalam mengikuti proses pembelajaran. Salah satu media pembelajaran yang menarik yang dapat digunakan adalah media kartu bergambar (Picture Cards) (Wahyudi \& Marwiyanti, 2017). Picture cards adalah media visual yang berupa kartu yang didalamnya berisi gambar-gambar dan konsep-konsep yang terkait dengan materi pembelajaran (Maufur \& Lisnawati, 2017). Picture cards membantu siswa dalam memahami materi pembelajaran dengan lebih baik, sesuai dengan perkembangan kognitif siswa yang masih dalam tahap operasional konkret.

Banyak penelitian terdahulu yang telah mengkaji tentang penggunaan model Joyful learning dan media picture cards. Pertama, penelitian yang dilakukan oleh Mubhirah et al. (2018) menunjukkan bahwa model Joyful learning berkontribusi positif dalam meningkatkan hasil belajar kimia. Sejalan dengan hasil penelitian tersebut, penelitian yang dilakukan oleh Juliati \& Rafiqah (2017) juga menemukan bahwa model Joyful learning dapat meningkatkan minat belajar siswa. Selanjutnya, penelitian yang dilakukan oleh Aliputri (2018) menemukan bahwa media kartu bergambar dapat meningkatkan hasil belajar siswa. Sejalan dengan hasil penelitian tersebut, Fatimah (2017) mengemukakan bahwa media kartu bergambar dapat meningkatkan motivasi dan hasil belajar siswa. Penelitian-penelitian tersebut telah membahas tentang penggunaan model Joyful learning dan picture cards secara parsial. Belum ada penelitian yang mengkolaborasikan model joyful learning dengan picture cards, khususnya pada jenjang pendidikan dasar. Selain itu, penerapan model ini belum pernah diimplementasikan dalam pembelajaran daring. Oleh sebab itu, perlu dilakukan penelitian untuk mengkaji pengaruh model Joyful learning yang dikolaborasikan dengan picture cards terhadap minat belajar siswa sekolah dasar.

Penelitian ini bertujuan untuk menganalisis signifikasnsi peningkatan minat belajar siswa dalam pembelajaran IPS melalui model Joyful Learning berbasis Picture Cards. Penerapan model Joyful Learning dilaksanakan secara daring. Minat belajar siswa yang dimaksud mengacu pada ketertarikan siswa dalam mengikuti pembelajaran. 


\section{Metode}

Metode penelitian yang digunakan adalah Classroom Action Research (CAR). CAR atau Penelitian Tindakan Kelas berfungsi sebagai alat untuk menyelesaikan masalah-masalah yang muncul di kelas dan juga sebagai alat untuk in-service training, dimana guru menggunakan keterampilan dan metode-metode yang inovatif serta mempertajam kemampuan analitisnya (Khasinah, 2013). Classroom action research ini dilaksanakan di SD ENDE 5 Kecamatan Ende Tengah Kabupaten ENDE pada siswa kelas V tahun ajaran 2019/2020 yang berjumlah 21 orang. Pengumpulan data diperoleh melalui penyebaran angket, observasi tindakan dan test yang meliputi pre-test dan post-test. Siswa dikatakan mencapai ketuntasan belajar apabila mencapai KKM yang ditetapkan sekolah yakni memiliki skor 75 .

Dalam penelitian ini, model CAR yang digunakan adalah model Kemiss \& McTaggart yang meliputi beberapa fase tindakan yakni (1) Planning, (2) Acting \& Observing (implementation \& observation), (3) Reflecting, (Hopkins, 2014). Alur tindakan dalam model ini dapat dilihat melalui Gambar 1.

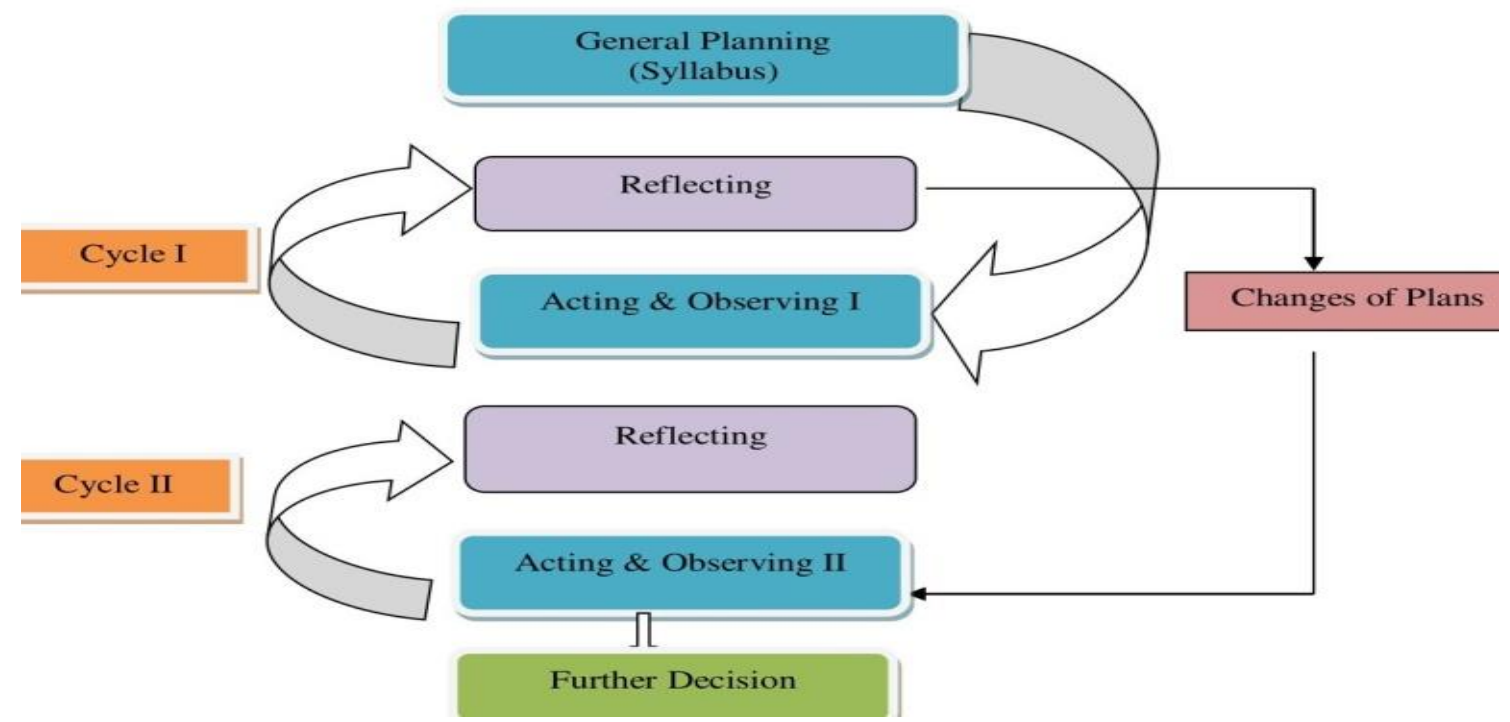

Gambar 1. Alur Classroom Action Research (Pali \& Rando, 2020)

\section{Hasil dan Pembahasan \\ Hasil}

Penelitian ini dilakasanakan dalam dua siklus tindakan. Kegiatan diawali dengan pre-test, observasi, wawancara dan penyebaran angket. Hal ini bertujuan umtuk mengetahui kondisi awal siswa dalam mengikuti pembelajajaran IPS secara khusus pada minat belajar siswa. Selain itu juga untuk mengetahui metode dan media pembelajaran yang digunakan guru dalam pembelajaran. Hasil pra research menunjukan fenomena menurunnya minat belajar siswa akibat kurang variatifnya guru dalam menerapkan metode dan menggunakan media dalam pembelajaran. Penurunan minat belajar ini juga berimbas pada hasil belajar siswa dimana tidak semua siswa mencapai standar ketuntasan. Hal ini diketahui dari hasil pre-test yang dilakukan dengan menggunakan 10 butir soal piihan ganda. Hasil pre-test memperoleh nilai rata-rata secara klasikal sebesar 66.16. Adapun persentase ketuntasan hasil pretest disajikan pada Gambar 2. 


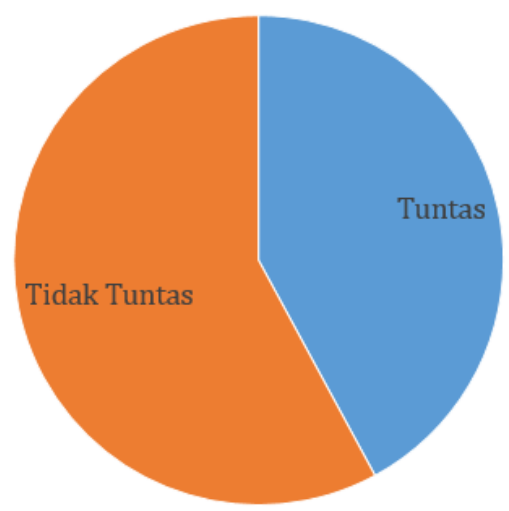

Gambar 2. Hasil Pretest

Berdasarkan kondisi awal yang disajikan pada Gambar 2, dapat diinterpretasikan bahwa jumlah siswa yang tidak tuntas lebih banyak dari jumlah siswa yang tuntas sehingga rencana tindakan pun dilakukan. Perencanaan tindakan diawali dengan analisis standar kompetensi dan kompetensi dasar untuk menentukan materi, mewawancara guru mata pelajaran Ilmu Pengetahuan Sosial untuk menganalisis materi yang sudah diajarkan guna penyesuaian penyusunan perangkat pembelajaran, membuat pemetaan silabus dan penyusunan Rencana Pelaksanaan Pembelajaran (RPP) dengan menerapkan Joyful learning berbasis Picture Cards. Selain itu juga menyiapkan Lembar Kerja Siswa (LKS), lembar observasi, serta angket untuk mengetahui minat belajar siswa yang akan dibagikan pada akhir tindakan.

Langkah selanjutnya adalah pelaksanaan tindakan pada siklus I. Pelaksanaan tindakan ini dijalankan berdasarkan scenario yang telah dirancang dalam RPP. Pada saat ini pula dilakukan observasi terhadap aktivitas guru maupun siswa. Hal ini bertujuan untuk mengetahui secara obyektif segala aktivitas guru dan siswa pada keseluruhan proses pembelajaran. Untuk aktivitas guru, terdapat 23 item yang diamati. Perolehan pengamatan terhadap aktivitas guru berjumlah 74 dengan presentasi sebesar 64, $35 \%$. Angka pencapaian aktivitas guru ini diklasifikasikan dalam kategori capaian cukup. Sedangkan untuk aktivitas siswa tersedia 15 apek yang diamati. Dari keseluruhan 15 aspek yang diamati ini, jumlah perolehannya adalah 57 dengan presentasi sebesar 69, 33\%. Presentasi aktivitas siswa ini diklasifikasikan dalam kategori sedang.

Kegiatan pada siklus ini dilanjutkan dengan pemberian post-test. Hasil post-test pada siklus 1 menunjukan adanya peningkatan jika dibandingkan dengan hasil tes pada pre-test yakni dari 42,11\% ketuntasan meningkat menjadi 57. 89\%. Kegiatan di siklus ini diakhiri dengan pengisian angket yang berisikan 30 butir pernyataan yang berkenaan dengan minat belajar siswa.

Prosentasi minat belajar siswa pada siklus tindakan pertama ini adalah 52,63\%. Skor tersebut berada pada interval 91-120 dengan rata-rata klasikal sebesar 84,21. Capaian ini diklasifikasikan dalam kategori sangat baik. Meskipun minat siswa pada siklus ini berkategori sangat baik namun hal ini masih ironis dengan capaian pada observasi aktivitas dan hasil belajar siswa yang belum sesuai dengan target capaian yang diharapkan. Untuk itu, dilakukan refleksi tindakan pada akhir siklus. Hasil analisis dan refleksi pada siklus ini melahirkan kesimpulan bahwa penelitian ini dilanjutkan pada siklus tindakan berikutnya.

Merujuk pada hasil analisis dan refleksi pada siklus sebelumnya, maka pada siklus lanjutannya didahului dengan perencanaan pembelajaran. Kegiatan perencanaan pembelajaran pada siklus ini tidaklah jauh berbeda dengan siklus sebelumnya yakni persiapan RPP dengan scenario joyful learning, media pembelajaran berupa picture cards yang berkaitan dengan materi pembelajaran, menyiapkan lembar observasi, angket tentang minat belajar, dan juga instrument tes.

Selanjutnya adalah pengaplikasian perencanaan pembelajaran dalam tindakan pembelajaran. Kegiatan diawali dengan berdoa bersama, kemudian dilanjutkan dengan mengecek presensi dan mengatur tempat duduk peserta didik, melakukan apersepsi dengan tanya jawab dan menyampaikan tujuan pembelajaran. Pada kegiatan inti pembelajaran dilaksanakan dengan menerapkan pendekatan joyful learning dengan permainan menyusun puzzle picture cards yang berhubungan dengan materi 
ajar yakni Jenis-Jenis Kegiatan Ekonomi. Selain menyusun puzzle picture cards, siswa juga diarahkan untuk menebak gambar terkait dengan materi ajar yang bersangkutan. Kegiatan inti diakhiri dengan penyimpluan materi oleh guru dan siswa, penyelesaian soal tes oleh siswa dan pengisian angket minat belajar siswa.

Dalam pengaplikasian tindakan siklus ini, observasi terhadap aktivitas dan tingkah laku guru dan siswa tetap dilaksanakan. Hasil observasi aktivitas guru terhadap 23 aspek yang diamati adalah 83 dengan presentasinya sebesar 72,17\%. Angka ini diklasifikasikan dalam kategori pencapaian tinggi. Kategori yang sama pun terlihat pada aktivitas siswa dengan presentasinya sebesar $73,12 \%$. Selain perolehan hasil observasi aktivitas guru dan siswa, pada siklus ini pun dilaksanakan post test. Hasil post test menunjukan adanya peningkatan nilai. Prosentase hasil post test pada siklus ini adalah 100 $\%$. Secara keseluruhan, peningkatan nilai test pada penelitian ini dapat dirangkum pada Tabel 1.

Tabel 1. Peningkatan Hasil Belajar Siswa

\begin{tabular}{ll}
\hline Jenis Test & Persentase (\%) \\
\hline Pre-Test & 42,11 \\
Post-Test Siklus I & 57,89 \\
Post-test Siklus II & 100 \\
\hline
\end{tabular}

Hasil belajar tersebut di atas tidak terlepas dari minat belajar siswa. Analisis angket minat belajar dalam siklus ini diklasifikasikan dalam kategori sangat baik. Hal ini dilihat dari perolehan persentase minat belajar peserta didik sebesar $68,42 \%$ dengan kualifikasinya pada interval antara 91120 dan rata-rata klasikal sebesar 91 dengan nilai perkembangan minat sebesar 6,79. Minat belajar siswa pada penelitian ini dapat dirangkum dalam Tabel 2.

Tabel 2. Peningkatan Minat Belajar Siswa

\begin{tabular}{lllc}
\hline Tindakan & $\begin{array}{c}\text { Prosentase Minat } \\
\text { Belajar (\%) }\end{array}$ & Rata-Rata Klasikal & $\begin{array}{c}\text { Nilai Peningkatan } \\
\text { minat }\end{array}$ \\
\hline Siklus I & 52,63 & 84,21 & \\
Siklus II & 68,42 & 91.00 & 6,79 \\
\hline
\end{tabular}

Tabel 2 menunjukkan terjadinya peningkatan minat belajar siswa pada setiap siklus tindakan. Hal ini dikarenakan oleh keberhasilan guru dalam menerapkan joyful learning berbasis picture cards. Pendekatan ini mampu membangkitkan minat belajar siswa di era new normal ini secara khusus pada pembelajaran IPS. Selain minat belajar siswa, peningkatan pun terjadi pada aktivitas belajar mereka yakni. $49,33 \%$ pada siklus I menjadi sebesar $70,67 \%$ pada siklus II. Sedangkan untuk aktivitas guru pada siklus I dan siklus II adalah 64, 35\% dan 72,17\%. Peningkatan aktivitas belajar siswa pada penelitian ini dapat dirangkum pada table berikut:

Tabel 3. Peningkatan Aktivitas Belajar Siswa

\begin{tabular}{lcc}
\hline \multicolumn{1}{c}{ Tindakan } & Prosentas Aktivitas Siswa & Nilai Peningkatan Aktivitas Siswa \\
\hline Siklus I & 49,33 & $21,34 \%$ \\
Siklus II & 70,67 & \\
\hline
\end{tabular}

\section{Pembahasan}

Peningkatan nilai, aktivitas dan minat belajar siswa pada setiap siklus tindakan di atas menunjukan bahwa pendekatan joyful learning berbasis picture cards pada pembelajaran IPS memberikan dampak yang positif. Temuan ini relevan dengan penelitian yang dilakukan oleh (Mubhirah et al., 2018) yang menyimpulkan bahwa penerapan model pembelajaran Joyful Learning dengan media kartu aksi memberikan pengaruh yang lebih baik terhadap hasil belajar Kimia pada materi koloid siswa kelas XI MIA MAN 2 Model Mataram. Selain itu juga hasil penelitian ini relevan dengan temuan yang dilakukan oleh (Mubhirah et al., 2018) yang menghasilkan kesimpulan bahwa metode enjoyfull learning efektif dalam meningkatkan minat belajar siswa di SMA Negeri 1 Bolo Kab. Bima serta temuan yang dilakukan oleh (Huro et al., 2015) yang menunjukan adanya peningkatan 
minat dan prestasi belajar Matematika setelah penerapan metode joyful learning pada siswa kelas VIIG SMP Negeri 2 Sanden Tahun ajaran 2012/2013.

Model Joyful Learning adalah model pembelajaran yang menekankan pada pembelajaran aktif dan mengkolaborasikan konsep dan praktik sehingga menghasilkan pembelajaran yang bermakna (Anggoro et al., 2017; Fisher et al., 2015; Proity, 2015). Joyful learning memiliki unsur inner motivation yang dapat memicu dan mendorong siswa untuk memiliki daya juang dalam mencari tahu sesuatu (ilmu) yang baru (Huro et al., 2015; Juliati \& Rafiqah, 2017; Mubhirah et al., 2018). Model Joyful learning mendukung situasi pembelajaran yang aktif dan membangkitkan motivasi siswa dalam belajar. Seiring dengan meningkatnya motivasi belajar siswa, terjadi juga peningkatan minat dan hasil belajar siswa (Anggoro et al., 2017; Azzahra \& Hasan, 2018).

Selain dengan menerapkan model pembelajaran yang inovatif, upaya peningkatan minat belajar siswa dapat dilakukan dengan menggunakan media pembelajaran yang menarik dalam proses pembelajaran (Asyhar, 2012; Ulfah \& Soenarto, 2017). Media pembelajaran yang menarik dapat meningkatkan ketertarikan siswa dalam mengikuti proses pembelajaran. Salah satu media pembelajaran yang menarik yang dapat digunakan adalah media kartu bergambar (Picture Cards) (Wahyudi \& Marwiyanti, 2017). Picture cards adalah media visual yang berupa kartu yang didalamnya berisi gambar-gambar dan konsep-konsep yang terkait dengan materi pembelajaran (Maufur \& Lisnawati, 2017). Picture cards membantu siswa dalam memahami materi pembelajaran dengan lebih baik, sesuai dengan perkembangan kognitif siswa yang masih dalam tahap operasional konkret.

Hasil temuan penelitian ini memberikan kontribusi dalam pengembangan kualitas pembelajaran. Model Joyful learning berbasis picture cards dapat digunakan sebagai upaya dalam mengatasi permasalahan yang ada dalam proses pembelajaran. Hasil penelitian ini dapat dijadikan sebagai referensi dalam penyelenggaraan penelitian-penelitian yang terkait dengan peningkatan kualitas output pembelajaran.

\section{Simpulan}

Penerapan Joyful Learning berbasis Picture Cards pada Pembelajaran IPS memberikan dampak yang signifikan pada peningkatan minat belajar siswa. Peningkatan minat belajar siswa ini berimbas pula pada peningkatan hasil belajar siswa. Model Joyful learning berbasis picture cards dapat digunakan sebagai upaya dalam mengatasi permasalahan yang ada dalam proses pembelajaran Oleh karena itu, pendekatan joyful learning bebasis picture cards dapat dijadikan salah satu metode alternatif dalam proses pembelajaran IPS di sekolah dasar.

\section{Daftar Pustaka}

Aliputri, D. H. (2018). Penerapan Model Pembelajaran Kooperatif Tipe Make A Match Berbantuan Kartu Bergambar Untuk Meningkatkan Hasil Belajar Siswa. Jurnal Bidang Pendidikan Dasar, 2(1), 70-72. https://doi.org/10.21067/jbpd.v2i1A.2351.

Anggoro, S., Sopandi, W., \& Sholehuddin, M. (2017). Influence of Joyful Learning on Elementary School Students'Attitudes Toward Science. Series: Journal of Physics: Conf. Series 812 (2017) 012001, 755(1). https://doi.org/10.1088/1742-6596/755/1/011001.

Aqib, Z., \& Murtadlo, A. (2016). Kumpulan Metode Pembelajaran Kreatif dan Inovatif. Sarana Tutorial Nurani Sejahtera.

Asyhar, R. (2012). Kreatif Mengembangkan Media Pembelajaran. Referensi Jakarta.

Azzahra, F., \& Hasan, Y. (2018). Meningkatkan Keterampilan membuat Piring Anyaman Lidi melalui Strategi Joyful Learning bagi Anak Tunagrahita Ringan. Penelitian Pendidikan Kebutuhan Khusus, 6(2006), 200-205. ejournal.unp.ac.id/index.php/jupekhu.

Basilaia, G., \& Kvavadze, D. (2020). Transition to Online Education in Schools during a SARS-CoV-2 Coronavirus (COVID-19) Pandemic in Georgia. Pedagogical Research, 5(4). https://doi.org/10.29333/pr/7937.

Cahapay, M. B. (2020). Rethinking Education in the New Normal Post-COVID-19 Era: A Curriculum Studies Perspective. Aquademia, 4(2), ep20018. https://doi.org/10.29333/aquademia/8315.

Crawford, J., Butler-henderson, K., Rudolph, J., Malkawi, B., Glowatz, M., Magni, P. A., \& Lam, S. (2020). COVID-19: 20 countries' higher education intra-period digital pedagogy responses. Journal of Applied Learning \& Teaching, 3(1). https://doi.org/10.37074/jalt.2020.3.1.7. 
Fatimah, I. D. (2017). Penerapan Model Pembelajaran Make a Match dengan Media Kartu Bergambar untuk Meningkatkan Motivasi dan Hasil Belajar Siswa. Ilmu Pendidikan: Jurnal Kajian Teori Dan Praktik Kependidikan, 2(1), 28-37. https://doi.org/10.17977/um027v2i12017p028.

Firman, \& Rahman, S. R. (2020). Pembelajaran Online di Tengah Pandemi Covid-19. Indonesian Journal of Educational Science (IJES), 2(2), 81-89. https://doi.org/10.31605/ijes.v2i2.659.

Fisher, B. M. E., Stockbridge, K., Dorner, M., Evensen, C. A., Maghzi, K., Pearson, H., \& Cuddy, E. (2015). Mapping Joyful Teaching and Learning: Multiple Perspectives on the Active, Collaborative Learning Environment Mapping Joyful Teaching and Learning: CCNews: Newsletter for the California Council on Teacher Education, 23(4), 23-26.

Gamage, K. A. A., Wijesuriya, D. I., Ekanayake, S. Y., Rennie, A. E. W., Lambert, C. G., \& Gunawardhana, N. (2020). Online Delivery of Teaching and Laboratory Practices: Continuity of University Programmes during COVID-19 Pandemic. Education Sciences, 10(10), 291. https://doi.org/10.3390/educsci10100291.

Hopkins, D. (2014). A Teacher's Guide to Classroom Research (Fifth). Open University Press.

Huro, F. B., Program, P., Pendidikan, S., Sarjanawiyata, U., \& Yogyakarta, T. (2015). Upaya Meningkatkan Minat Dan Prestasi Belajar Matematika Dengan Metode Joyful Learning Pada Siswa Kelas VIIG SMP Negeri 2 Sanden Tahun Pelajaran 2012/2013. UNION: Jurnal Ilmiah Pendidikan Matematika, 3(1), 97-102. https://doi.org/10.30738/.v3i1.289.

Juliati, N., \& Rafiqah. (2017). Efektivitas Penerapan Metode Enjoyfull Learning dalam Peningkatan Minat Belajar Siswa Kelas X SMA Negeri 1 Bolo Kab. Bima. Pendidikan Fisika, 5(1), 66-69. http://repositori.uin-alauddin.ac.id/3395/1/NILA JULIATI.pdf.

Karalis, T. (2020). Planning and evaluation during educational disruption: Lessons learned from Covid19 pandemic for treatment of emergencies in education. European Journal of Education Studies, 7(4), 2020. https://doi.org/10.5281/zenodo.3789022.

Khasinah, S. (2013). Classroom action research. Pionir, 4(1), 1-9. https://doi.org/10.22373/pjp.v4i1.159.

Maufur, S., \& Lisnawati, S. (2017). Pengaruh Penggunaan Media Gambar Berseri Terhadap Keterampilan Berbicara Bahasa Indonesia Siswa Kelas III MI Al-Washliyah Perbutulan Kabupaten Cirebon. Al Ibtida: Jurnal Pendidikan Guru MI, 4(2), 189. https://doi.org/10.24235/al.ibtida.snj.v4i2.1888.

Mubhirah, Q. U., Muntari, \& Idrus, S. W. Al. (2018). Chemistry Education Practice Pengaruh Model Pembelajaran Joyful Learning Dengan Media Kartu Aksi Terhadap Hasil Belajar Kimia Materi Koloid Pada Siswa Kelas Xi Mia Man 2 Model Mataram the Influence of Learning Model Joyful Learning With Action Card Media. Chemistry Education Practice, 1(1), 27. https://doi.org/10.29303/cep.v1i1.886.

Pali, A., \& Ota, M. K. (2020). Pendampingan Kegiatan Fun With English Pada Serikat Anak Misioner (SEKAMI) Stasi St. Keusukupan Agung Ende, Flores, NTT. SELAPARANG.Jurnal Pengabdian Masyarakat Berkemajuan, 4(November), 278-283. https://doi.org/10.31764/jpmb.v4i1.2884

Pali, A., \& Rando, A. R. (2020). Suggestopedia Method Application Based on Sasando Instrumental Music in Optimizing Reading Comprehension Skills. Jurnal Ilmiah Pendidikan Dan Pembelajaran, 4(3), 522-528. https://doi.org/10.23887/jipp.v4i3.28216.

Proity, S. H. (2015). Effect of Joyful Teaching on Grade IV Students "Academic Performance in Science. International Journal of Science and Research (IJSR), 4(10), 1232-1240. https://pdfs.semanticscholar.org/0d1b/d23c899d03160e99db032044aa5cd985adde.pdf.

Shoimin, A. (2014). Model pembelajaran Inovatif dalam Kurikulum 2013. AR-RUZZ MEDIA.

Tria, J. Z. (2020). The COVID-19 Pandemic through the Lens of Education in the Philippines: The New Normal. International Journal of Pedagogical Development and Lifelong Learning, 1(1), ep2001. https://doi.org/10.30935/ijpdll/8311.

Ulfah, D. M., \& Soenarto, S. (2017). Pengaruh penggunaan media video dan gambar terhadap keterampilan menulis kelas V. Jurnal Prima Edukasia, 5(1), 22-34. https://doi.org/10.21831/jpe.v5i1.7693.

Wahyudi, D., \& Marwiyanti, L. (2017). Penerapan Model Pembelajaran Inside Outside Circle Dalam Mata Pelajaran Akidah Akhlak. Jurnal MUDARRISUNA: Media Kajian Pendidikan Agama Islam, 7(2), 267-292. https://doi.org/10.22373/jm.v7i2.2369.

Wargadinata, W., Maimunah, I., Dewi, E., \& Rofiq, Z. (2020). Student's Responses on Learning in the 
Early COVID-19 Pandemic. Tadris: Jurnal Keguruan Dan Ilmu Tarbiyah, 5(1), 141-153. https://doi.org/10.24042/tadris.v5i1.6153.

Wijayanengtias, M., \& Claretta, D. (2020). Student Perceptions of Online Learning During the Covid-19 Pandemic. Kanal: Jurnal Ilmu Komunikasi, 9(1), 16-21. https://doi.org/10.21070/kanal.v9i1.685.

Wijoyo, H., \& Indrawan, I. (2020). Model Pembelajaran Menyongsong New Era Normal Pada Lembaga Paud Di Riau. JS (Jurnal Sekolah) Universitas Negeri Medan, 4(3), 205-212. https://doi.org/10.24114/js.v4i3.18526.

Xin, Y. P., Park, J. Y., Tzur, R., \& Si, L. (2020). The impact of a conceptual model-based mathematics computer tutor on multiplicative reasoning and problem-solving of students with learning disabilities. The Journal of Mathematical Behavior, 58. https://doi.org/10.1016/j.jmathb.2020.100762.

Xue, Q., Xie, X., Liu, Q., Zhou, Y., Zhu, K., Wu, H., Wan, Z., Feng, Y., Meng, H., Zhang, J., Zuo, P., \& Song, R. (2021). Knowledge, attitudes, and practices towards COVID-19 among primary school students in Hubei Province, China. Children and Youth Services Review, 120(November 2020), 105735. https://doi.org/10.1016/j.childyouth.2020.105735. 